\title{
WHEN A COMPATRIOT BECOMES A FOE Political Parties and Violent Elections in Kenya and South Africa
}

\section{John Rabuogi Ahere}

John Rabuogi Ahere is a conflict management practitioner and researcher with interest in international politics and its linkage to peace, security and development. He is currently a PhD candidate of Peace Studies at the University of New England in Armidale, Australia

\begin{abstract}
This paper examines the operations of political parties in Kenya and South Africa and provides an analysis of how such operations have become drivers of election violence. The paper contends that as a result of the structure of political parties and how they operate, they have contributed to the violence that has become an endemic feature of the electoral processes in both countries. In Kenya, most election violence has been between supporters of different political parties who contest election outcomes. In South Africa, even though there were many incidents of inter-party violence in the 1990s, recent trends indicate reductions of the same but with an increase in intra-party violence, especially over disputed party lists.
\end{abstract}

Keywords: political parties, election violence, Kenya, South Africa

\section{INTRODUCTION}

In many African countries, discussions about upcoming general elections often focus on the uncertainties that accompany them. This is due to the fact that political violence has become a feature in many of these elections. There are different viewpoints regarding this recurrence of violence. Some attribute it to weak political and electoral institutions whose malfeasance encourages brinkmanship by political opponents keen to have an edge over each other (Kimemia 2016, p. 215). Others attribute election violence to accumulated structural problems which have not been addressed (Ahere 2012, p. 29).

Elections in Kenya and South Africa have been plagued by violence. Ruteere and Wairuri (2015, p. 113) affirm that since 1991, every general election cycle in 
Kenya has been accompanied by deaths, injuries, displacements and wanton destruction of property. South Africa has also witnessed incidents of violence during election periods, with concerns raised over the number of political killings during municipal and local government elections (Associated Press 2016, para. 1).

Political parties are linked to the contestations during election cycles since they act as clearing houses for candidates seeking elective office. By their very nature political parties also aim to obtain and control political power. The contestations for political power in both countries are always at fever pitch due to the patron-client nature of both political systems, exacerbated by high levels of unemployment (Yoder 2015, p. xiii). It follows, therefore, that because of these contestations, the activities of political parties contribute to election violence in both countries. A notable example is the 2008 post-election violence (PEV) in Kenya which pitted supporters of the Orange Democratic Movement (ODM) against those of the Party of National Unity (PNU) (Njogu 2009, p. 4). Another example is the violence on the eve of the 1994 elections in South Africa in which there were deadly clashes between African National Congress (ANC) and Inkatha Freedom Party (IFP) supporters (Rickards \& Haitsma 2014).

This paper examines the operations of political parties in Kenya and South Africa and provides an analysis of how such operations have become drivers of election violence. The paper focuses on certain elements identified in the methodological note below and uses these elements to discuss election violence in both countries.

\section{METHODOLOGY}

The information used in this paper was obtained from both primary and secondary sources. The primary sources include news articles, blogs, workshop reports, civil society organisation (CSO) activity reports, research reports and speeches. Secondary sources were mainly from peer-reviewed journals, books, and dissertations.

By reviewing research of a similar nature, some cross-cutting elements were identified. These include:

- typologies of electoral systems

- institutional strengths of political parties

- the process of recruiting party members

- policy formulation by political parties

- accession to party leadership and member nominations for elective offices

- dispute resolution within the political parties. 
These elements are used in this paper to explain the activities of political parties and how they are drivers of election violence.

\section{ELECTORAL SYSTEM TYPOLOGIES}

There are different types of electoral systems in Africa and the preferred system in each country normally influences the motivation and zeal with which members of political parties consider seeking elective office. With respect to those that are prevalent in Africa, André, Depauw and Martin (2016, p. 42) identify two electoral systems: those that are party-centred, and those that are candidate-centred. On the other hand, Teorell and Lindstedt (2010, p. 434) compare electoral systems by examining how citizens cast their votes and what they vote for, the number of districts that exist and the seats available for each district, and how votes are converted into seats. Regardless of the system, most elections in Africa are zerosum in nature and take place under difficult political conditions.

\section{Kenya's mixed Electoral Representation}

From 1963 to 2007, Kenya's electoral system was first-past-the-post (FPTP). The FPTP system uses single-member districts and is candidate-centred. The voter is presented with ballot papers containing the names of nominated candidates and votes by choosing only one of them for the particular seat stated on the ballot. The candidate who obtains the most votes is deemed to be the winner even if he or she has fewer votes than the other candidates combined (Reynolds, Reilly \& Ellis 2008, p. 28).

Following the promulgation of the 2010 Constitution, Kenya adopted an electoral system that was primarily FPTP but included some elements of proportional representation (PR). In the general elections held every five years, voters elect the president, senators and members of parliament (MPs) directly, as well as county governors alongside members of county assemblies (MCAs). With the exception of the office of the president, all other elective offices are elected through FPTP. For a president to be elected, he or she must garner more than $50 \%$ of the votes and also receive $25 \%$ of the vote in at least 24 counties (Kenya 2010, Art. 138(4)). If the winning candidate fails to satisfy the aforementioned percentage, then a runoff is held between the top two candidates whereby the winner receives the most votes.

During a general election, there are special seats in parliament and the county assemblies elected through PR via the use of party lists. Each political party participating in a general election is required to provide to the Independent Electoral and Boundaries Commission (IEBC) a list of those who will stand elected 
if the party were to be entitled to extra seats (Dundas 2012, p. 202). These extra seats are allocated to political parties in proportion to the total number of seats won by candidates of the political party at the general election (Kenya 2010, Art. 90).

The current electoral system is the result of a long-running discourse on how to reduce the zero-sum nature of politics that contributed to, among others, the 2008 PEV.

\section{South Africa's Proportional Representation System}

The apartheid era had a structurally problematic electoral system as far as social cohesion was concerned. From 1910 to 1991 South Africa used the plurality district system in a political system in which the majority black South Africans were disenfranchised. Forest (2007, p. 381) stresses that even among the minority eligible to vote, the system created disproportionality in the sense that it allowed for a situation in which one party (National Party) was able to receive just over $50 \%$ of the vote on average but typically win up to $75 \%$ of the seats in parliament.

Louw (2014, para. 1) affirms that South Africa's post-apartheid electoral system was carefully considered in a bid to promote inclusiveness in governance and also to encourage a coalition government. The PR system was adopted and this allocates seats in direct proportion to the number of votes a party receives. This system allows smaller parties to have a stake, thereby enhancing inclusivity. Under the PR system, each party develops a list of candidates for the National Assembly and the nine provincial legislatures. Voters, who are of the minimum age of 18 and registered on the voters' roll, use two ballots - one national and the other provincial - to cast votes for the party of their choice (Booysen \& Masterson 2009, p. 401). The intention of the PR system is to reduce the disparity between a party's share of the national vote and its share of the parliamentary seats. In essence, if a dominant party wins $x \%$ of the votes, it should win approximately $x \%$ of the seats, and a small party with $y \%$ of the votes should also gain $y \%$ of the legislative seats (Reynolds, Reilly \& Ellis 2008, p. 29).

South Africa uses the closed-list proportional representation system for its national, provincial and half of all municipal and local government elections. Piper (2012, p. 31) clarifies that at the local level, a mixed electoral system applies, wherein half of the councillors are elected in FPTP ward elections, and the other half in terms of PR on local lists. This mixed system offers voters the opportunity to seek accountability from grassroots politicians whom they elect directly. This is in the wake of a major criticism of the PR system which has been said to make politicians loyal more to the parties that nominated them than to the voters. 


\section{INSTITUTIONALISATION OF POLITICAL PARTIES}

According to organisation theory, institutionalisation means making an entity work through strengthening its structures, especially internal structures, in order to obtain some equilibrium with the external environment (Friedrich Ebert Stiftung 2010, p. 31). Institutional theorists focus on leadership, organisation membership and loyalty, and internal structural features such as the organisation of offices, goals of the organisation, and fiscal resources.

In their study of African political parties, Basedau and Stroh (2008, p.3) identify four elements that can be used in measuring the levels of institutionalisation of political parties:

- coherence and cohesion

- degree of societal integration

- level of organisation

- the party's appearance as an independent organisation.

All the aforementioned elements manifest themselves in different ways in the following examination of political parties in Kenya and South Africa.

\section{Low Levels of Institutionalisation in Kenya}

The institutionalisation of political parties in Kenya has been described as complex and disjointed. Having examined Kenyan political parties from four different perspectives, Mutizwa-Mangiza (2013, p. 295) finds that political party institutionalisation is in its infancy in terms of contributing meaningfully towards democratic consolidation.

Firstly, he asserts that most parties exhibit low levels of organisational systemisation, that is regarding internal cohesion and levels of modus operandi. There are many incidences of politicians switching political parties for their own political survival rather than for ideology or policy. This is often preceded by prolonged intra-party disagreements between members. Recent examples, that is between 2003 and 2007, include the splits of the Liberal Democratic Party (LDP) from the National Rainbow Coalition (NARC) and ODM-Kenya (ODM-K) party from ODM (Wiafe-Amoako 2016, p. 224). Many political parties have also failed to adhere to their own constitutions and some existed only on paper as they had no operational structures.

Secondly, members of political parties have low degrees of commitment beyond 'instrumental and self-interested incentives' as evidenced by constant defections (Mutizwa-Mangiza 2013, p. 23). This is because the political parties are 
not primarily driven by ideologies which can inspire like-minded actors towards policy-oriented directions. Even when political parties have die-hard supporters, this is often as a result of support for an individual or individuals rather than for party manifestos.

Thirdly, analysis of the many political parties in Kenya that participated in the 2017 general elections indicates that only two can be said to pass the test of reification. Reification, or objectification, refers to the extent to which a party's existence is established in the public imagination (Mutizwa-Mangiza 2013, p. 289). A few large parties dominate the political scene at the expense of the others and this is partly due to the way in which pre-election political coalitions are crafted on ethnic considerations that focus on powerful individuals from the larger tribes.

Fourthly, political parties in Kenya have been found to be fairly immune from interference by and undue influence of other organisations regarding policy formulation. This is attributed to the fact that many parties are closely identified with their party leaders who also act as the main financiers. Many parties also have limited affiliations to other civil society organisations that would otherwise influence their decisional autonomy (Mutizwa-Mangiza 2013, p. 290).

\section{Longevity of Political Organisation in South Africa}

Post-apartheid South Africa is said to have one of the strongest democracies in Africa, but one which presents an interesting scenario in the dominance of the political agenda by the ANC. The opposition's lack of numerical strength has led to an absence of robust competition with the ANC. This has cultivated seeds of discontent within the party because the governing party has low levels of accountability which have become a source of frustration within party structures. This has created intra-party opposition that continues to fracture the party (Cohen \& Mbatha 2017, para. 1). These fractures have fanned scholarly debate about how a dominant party system like South Africa, in which the ANC has won all the elections since 1994, can stunt the process of democratisation throughout the political party system (Diamond 2008, p. 8). O'Dwyer (2006, p. 187) warns that the dominance of one party in a political system can lead to a situation where the avenues available to the opposition to check the government are eroded by the dominant party.

That said, it is noteworthy that with the exception of the Economic Freedom Fighters (EFF), the main parliamentary political parties in South Africa have existed for long periods in one form or another. Due to this longevity, most major political parties have served the useful function of recruiting their members, including those who eventually head them. This is in contrast to Kenya, where 
all parliamentary parties (except KANU ${ }^{1}$ ) have been formed by their current leaders/members. Randall and Svåsand (2002, p. 34) believe that this recruitment function plays a major role in cultivating party ideology since these institutions have had time to develop solid strategic directions in so far as policy is concerned.

There is a contention that South African politics is still structured along historical ties that overlap with ethnic and racial identity. This manifests itself in the sense that many parties in opposition to the ANC are considered niche parties which do not strive for nationwide majority but represent a certain religious or ethnic group (Kaßner 2014, p. 209).

Ultimately, an examination of the major political parties in South Africa reveals that they have comparatively well-institutionalised party systems as they have had committed and durable support bases, consistent policies emanating from periodic conferences, and well-structured internal organisations led by professional full-time officials (Lodge 2004, p. 217). They have also had good connections with interest groups that have provided activist loyalty which contributes to policymaking. One of the key indications of a party's strength is when the organisation can survive its charismatic founder (Huntington 2006, p. 409). An assessment of the major political parties that have performed consistently in post-apartheid elections indicates that they have survived significant leadership transitions.

\section{RECRUITMENT OF PARTY MEMBERS}

For a political party to be successful in winning elections, it must be able to mobilise and recruit many members who can assist it in accessing and influencing potential voters. According to Hofmeister and Grabow (2011, p. 35), there are a number of ways in which a party can recruit its members. These include personal contact, organising public events, presentations or public debates, and public hearings on topical concerns in local politics.

In Kenya and South Africa, even though major political parties recruit their members through the aforementioned ways, there are certain characteristics that influence those who decide to join. That said, political parties retain the right to decide on who becomes a member (Office of the Registrar of Political Parties of Kenya 2014, p. 1).

\section{The Ethno-regional Factor in Kenya}

During the period from 1982 to 1991 when Kenya was a de jure one-party state, KANU recruited its members through members of the provincial administration,

1 Kenya African National Union. This party was founded in May 1960. 
historically considered despotic (Otenyo 2016, p. 117). As a result, many became members of the party simply because they did not want to attract the wrath of the administrators. A political culture was created in which political party membership was not valued, since the recruitment was not based on the mutual interests of the parties and the members. The reintroduction of a multi-party system in 1991 led to massive defections of KANU members opposed to it. Some of the aforementioned defectors went on to form opposition parties which participated in the 1992 general elections and opposed KANU. Henceforth, there was general apathy towards membership of political parties even though many voters associated with these parties, especially during election periods. Party membership was mainly for the party elites who wanted to use it either to contest elections or to negotiate political benefits.

Ogendi (2015, p. 150) posits that political parties in Kenya are yet to develop effective recruitment mechanisms and this is because the political culture in Kenya does not support active membership participation. He also notes that there have been instances when political parties, in complete disregard of the law, recruited members without their knowledge by using details obtained from different databases. This became a contentious public issue until the Registrar of Political Parties allowed digital public queries of its database so that individuals could confirm if they genuinely belonged to political parties (Lang'at 2017, para. 3).

Fraudulent recruitment of members by parties was occasioned by the enactment of a law stating that only political parties with membership lists would be allowed to participate in elections (Kenya 2015, s. 7). Filed with the Registrar of Political Parties, the list of members is supposed to demonstrate that the parties have at least 1000 registered voters from each of more than half of the counties in Kenya.

Even though the Constitution of Kenya theoretically prohibits the formation of parties on a purely ethnic or regional basis, the reality is that ethnic configurations play a major role in the formation of pre-election coalitions. Luminaries of the parties within coalitions, or those who lead dominant parties, often rely on their ethnic bases as a means for negotiating with others (Barnet 2017, p. 41). It is no wonder that some parties are synonymous with the ethnic groups or regions associated with their leaders.

\section{The Legacy of Race-based Party Membership in South Africa}

Because of South Africa's history of political discrimination, the recruitment of members by political parties and organisations was for a long time determined by racial, ethnic and regional considerations. During the apartheid era, membership of political parties was largely determined by the fact that only white South 
African citizens were enfranchised. Botha (1996, p. 112) points out that the Prohibition of Political Interference Act (Act No. 51 of 1968) effectively outlawed mixed-race political parties by making it illegal for different population groups to be involved in each other's politics. The post-apartheid legacy of this dispensation can be seen in the fact that political parties may be registered and recruit members on the basis of ethnicity, religion, regionalism, tribalism, or advocacy of secession (Electoral Institute for Sustainable Democracy in Africa 2006, para. 4). This points to the desire of politicians to break away from any discriminatory laws that are reminiscent of the apartheid era.

There remain political parties that draw their membership from particular interests. These include Lusophones (Luso-South African Party), Indians (Minority Front Party), Christians (African Christian Democratic Party) and Muslims (African Muslim Party and the Islamic Party). It is important to note that these parties have not performed well during elections. Botha (1996, p. 118) concludes that their failures may be attributed to the fact that they have not succeeded in establishing well-integrated structures among their new recruits. It also points to their failure to establish strong coalitions or relationships with other minority parties that might allow them to challenge the main parties.

Being voluntary associations, political parties in South Africa are not generally regulated by statute. Prospective members are therefore recruited on the basis of the constitutions of the respective parties and such membership criteria is determined by the existing party members (Tiry 2012, p. 19).

\section{POLICY FORMULATION}

As vehicles for political expression, political parties often seek to influence the formulation of policies that are aimed at structuring societies in manners congruent with their visions. In his study of the programmatic content of political parties in non-industrialised societies, Elischer (2010, p. 23) found that parties demonstrate little concern for programmatic ideas. He also found that on issues such as democracy and human rights, political parties tend to care about them when selling their manifestos but that declines once the parties are in government. An assessment of policy formulation by political parties in Kenya and South Africa reveals some parallels and nuances.

\section{Weak Ideology of Kenya's Political Parties}

Kabeberi (2011, p. 119) postulates that political parties in Kenya are resistant to checks and balances in the manner in which they operate. This has made it difficult for them to adhere to principles on crucial areas such as corporate governance, financial management and membership development, which make institutions 
disciplined and strong. To this end, many parties have been found to relegate their manifestos to the periphery and instead focus on personality-based political tussles with the competition.

Indeed, it has become difficult for the electorate to tell the difference between the proposed development programmes of different political parties. Oloo (2007, p. 111) argues that this is due to the fact that the manifestos unveiled by parties in each election year have similar approaches to issues and are not overtly guided by ideologies. The net result is that voters do not identify with parties based on the programmes that are proposed but rather on other factors such as ethnicity and the charisma of their leaders.

\section{Elitism and Party Manifestos in South Africa}

A key feature of most major political parties in South Africa is the periodic organisation of policy conferences in which programmes are discussed (Jolobe 2009, p. 137; Siko 2014, p. 191). There has been criticism of these policy conferences as being elitist in nature (Walt 2013, p. 9). Nonetheless, the existence of such avenues is useful in laying foundations for issue- and ideology-based elections.

Shivambu and Smith (2014, p. 173) attack the manifestos of political parties, noting that none of the promises have been met since 1994. They also point out that none of the existing political parties is willing to develop programmes to ensure that the country's natural resources benefit all. This lends credence to Schreiner and Mattes' (2012, p. 162) assertion that the media in South Africa gives little coverage to party policies and instead focuses on party personalities. This can be attributed to the limited attempts by political parties to market their policies rather than their political representatives.

\section{ACCESSION TO PARTY LEADERSHIP AND NOMINATIONS FOR ELECTIVE OFFICES}

Across Africa, political party leadership is a highly controlled process with those close to the centre having a major say on who becomes a leader. Rarely do grassroots supporters have a genuine input in the process. In fact, many parties in Africa do not hold regular elections because party leaders fear the fallout by disgruntled members who tend to defect and form splinter parties (Kimemia 2016, p. 243).

Closely linked to the issue of party leadership is the process through which parties nominate their members to stand for elective posts during elections. In most African countries these have been acrimonious processes that have often led to violence. The sections below examine how these play out in Kenya and South Africa. 


\section{Poor Internal Democracy in Kenya's Political Parties}

Even within Kenya's major political parties, elections are rarely held and when these do take place they are characterised by chaos, and in many cases violence. Oloo (2007, p. 105) notes that although party constitutions and manifestos indicate their appreciation of democratic principles and justice, party leaders and top party organs routinely control not only who gets elected but also who gets nominated to contest general elections.

Political parties rarely convene national conferences. When they do, it is normally to rubberstamp (through acclamation) decisions about party leadership made by a cabal. As a result, national conferences are attended by carefully selected delegates, including some who are not party members.

In this configuration, it is difficult for outsiders - women, the youth and other marginalised groups - to accede to party leadership or to be nominated on the basis of their policies or popularity. All the aforementioned issues lead to splits, defections and the formation of new parties or the revival of moribund parties (Oloo 2007, p. 106).

\section{Democratic Centralism within South African Political Parties}

The major political parties in South Africa, notably the ANC and Democratic Alliance (DA), have elaborate processes for nominating candidates to run for elections. Booysen and Masterson (2009, p. 409) believe that these processes are anchored in internal democracy while noting that in smaller parties, the leadership has direct nomination powers. However, Kaßner (2014, p. 340) reasons that even though the ANC espouses democracy, there were periods during the leadership of Thabo Mbeki when strong centralisation tendencies increasingly limited democratic procedures. The idiosyncrasies of individual political party leaders can therefore determine the extent to which internal democracy is practised.

For most parties, the value of each member is determined by his or her loyalty to the decisions reached by the party as well as respect for the party and its leadership. The decision-making processes are such that issues should ideally to be debated internally until they are finalised, after which no further debate is normally allowed. This is what Vos (2017, p. 237) refers to as democratic centralism $^{2}$. Those who accede to leadership positions or are placed on party lists are therefore those who adhere to the aforementioned centralism.

2 In this system, even though party members may participate in elections and policy discussions at all levels, they must follow decisions made in the upper echelons of the party. 


\section{DISPUTE RESOLUTION}

Political parties in Africa often have drawn-out disputes. This is partly due to their nature as competitors, and also because respective political systems are burdened with historical contestations, especially over resource allocation. These disputes are both internal and external - not just between political parties but also within political parties. Because of a low observance of the principle of party supremacy wherein members put the interests of the party above their individual interests, intra-party disputes easily fester and weaken the political parties in question.

In examining inter-party disputes, Chukwuemerie (2009, p. 132) asserts that they often lead to dire consequences for the countries in which they occur. To this end, it is important that appropriate mechanisms are in place to deal with the disputes and resolve their root causes. Variations of political party dispute resolution mechanisms can be found in both Kenya and South Africa.

\section{Internal Dispute Resolution Mechanisms in Kenya's Political Parties}

Kenya's Political Parties Disputes Tribunal (PPDT) is an independent quasi-judicial body established by statute with the mandate to resolve the disputes of political parties (Kenya 2015, s. 39). The PPDT can hear and determine cases only after they have been discussed by the party's internal dispute resolution mechanisms. Each party is therefore obliged by law to have these mechanisms.

Nonetheless, political parties in Kenya experience constant fractures arising from the lack or inadequacies of internal dispute resolution mechanisms. Many disputants do not seem to have any faith in their own internal dispute resolution mechanisms. This has manifested itself in the high number of cases referred to the PPDT, especially after the holding of party primaries ahead of the 2017 general elections. At one point, the Independent Electoral and Boundaries Commission (IEBC) feared that the unprecedented number of disputes referred to the PPDT from the party nominations could derail preparations for the general election if the legal battles were prolonged (Oduor 2017, para. 2). Having said that, it is worth noting that some decisions of the PPDT were appealed at the High Court very close to the 2017 election date and this had an adverse impact on the schedule of ballot paper printing, thereby contributing to the logistical challenges that the IEBC faced.

\section{Alternative Dispute Resolution in South Africa}

In the last decade, the South African political system has witnessed the acceptance and strengthening of alternative dispute resolution and conflict management 
processes. This was in order to prevent the waves of violence that characterised the 1994 general elections as well as the 1995-96 municipal and local government elections. These waves of violence, however, continue to occur. Many political disputes, including those involving political parties, have been subjected to mediation, arbitration and conciliation processes which are considered to be an accessible, cost-effective and rapid means of addressing disputes (Booysen \& Masterson 2009, p. 418).

From 1999 a conflict management programme was developed in which early warning mechanisms were included in order to detect any potential electionrelated conflicts. The programme also included the organisational capacity to facilitate an effective resolution of disputes. Driven by the South African Independent Electoral Commission (IEC), this programme is executed through provincial-level conflict management committees which receive election-related complaints and propose ways of handling these amicably before they reach the courts or result in unrest (Booysen \& Masterson 2009, p. 419). There are, however, disputes that are not election-related which might not be resolved by these committees.

When disputes do arise which are not election-related, they are meant to be resolved in accordance with the internal regulations of the party concerned. This is because South African political parties are voluntary associations. In fact, 'the South African legal regime supports the formation and functioning of political parties with no intervention by the judiciary, provided the dispute is outside the court's domain' (Tiry 2012, p. 14). This is normally when the dispute is considered an internal party matter with no bearing on public interest. Many disputes have however been referred to courts when internal dispute resolution mechanisms have failed to satisfy the aggrieved members.

Having discussed some elements associated with the nature of the operations of political parties in Kenya and South Africa, the final section of this paper assesses how the interplay of these elements contributes to election violence.

\section{ELECTION VIOLENCE}

Since the wave of multipartyism that accompanied the fall of the Berlin Wall in 1989, more than $80 \%$ of the elections held in Africa witnessed some form of violence (Laakso 2007, p. 224). Election violence has continued to be a factor in many countries even though the levels have not been as high as those witnessed in the first rounds of elections in the multiparty era. In Kenya and South Africa many of the incidents of election-related violence have been driven by the activities of political parties, as elucidated below. 


\section{Election Violence in Kenya}

The manner in which Kenya's major political parties have structured the recruitment of their members has left the parties vulnerable to being perceived as ethnic parties with localised support in specific regions only. During recruitment the focus is on the region(s) where the ethnic compatriots of the top party leaders reside, as most electoral constituency boundaries mirror the traditional geographical spaces of ethnic groupings. As a result, political parties have created a situation in which their supporters consider some regions as their strongholds and where they are less tolerant of supporters of other parties. This is especially if the latter are associated with leaders from other ethnic groups considered as competitors in a particular election (Njogu 2009, p. 3).

The peak of the aforementioned intolerance was the 2008 PEV in which supporters of ODM and PNU unleashed violence against each other. This led to the deaths of at least 1000 people and serious injuries to 3500 others; in addition there were over 900 acts of documented rape and sexual violence, accompanied by the displacement of approximately 350000 people (International Criminal Court 2016, para. 3). As Njogu (2009, p. 3) notes, even though ODM leadership was required by law to file a court petition indicating their displeasure with the 2007 presidential election outcome, the lack of trust in the judiciary ${ }^{3}$ encouraged them to call their supporters to participate in mass action. By that time, latent conflict had incubated over a long period due to unresolved structural issues which had been created by several concerns, particularly the way in which KANU used its control over the security forces to clamp down on other political parties from 1967 to 1991. The flawed 2007 elections therefore became a trigger for the violence that had an ethnic perspective (Ahere 2012, p. 33; Kiruthu 2015, p. 66).

The internal systems within Kenya's political parties encourage competition rather than cooperation, the net result being the creation of factions. The percolation of such zero-sum cultures outside the parties possibly explains why, during the negotiation of the 2010 Constitution, respective parties preferred the FPTP system as opposed to any alternative system that would have helped to promote cooperation between political parties in state governance.

The FPTP electoral system that Kenya uses promotes a zero-sum style of politics in which political party leaders urge their ethnic groups to support them in order to benefit when they form the government. Losing an election is associated with loss of livelihood for the whole community or communities

3 Before its radical reforms in 2011 the Kenyan judiciary was '... an institution so frail in its structures; so thin on resources; so low on its confidence; so deficient in integrity; so weak in its public support...' that it was unable to deliver justice. This led to the popular joke: 'why hire a lawyer when you can buy a judge?'(Gainer 2015, pp. 1-2). 
associated with the leaders on the losing side. Political party coalitions have therefore been formed only for purposes of competing in elections and even then, their formations have taken ethno-regional dimensions. For that reason, a new government is always associated with the community of the president (Barnet 2017, p. 28). The opposition, on the other hand, is always associated with the communities of presidential election losers.

The internal structures of political parties have also created room for political party leaders to value political capital beyond anything else. Whether or not they are in government, they have condoned or orchestrated violence in order to keep such capital. Cases of this include the 1992 and 1997 general elections when the ruling party KANU orchestrated violence against opposition parties in the Rift Valley region and other 'KANU zones' (Friedrich Ebert Stiftung 2010, p. 29). The patterns of violence point to the growing culture of impunity whereby state authorities fail to respond with impartiality. This is because the party or coalition in power controls the law enforcement agencies and often uses them to victimise supporters of opposition parties, or the residents of areas in which opposition parties receive most support.

Political parties have also played a role in stoking election violence by failing to agree on legislation that would comprehensively reform key institutions (notably the IEBC) that have oversight of the electoral process. Whenever reforms have been proposed, they have not taken a multipartisan approach but instead focused on how the party or parties fronting such legislation would have an edge over the others during elections. As a result, the electoral system and IEBC have remained weak and vulnerable to systemic political party-driven manipulations that have made presidential elections outcomes suspicious (Kiruthu 2015, p. 66).

Another angle that can be used to examine election violence is the periodic calls for mass action by political parties. Whenever political parties have called for mass action, and these have occurred around issues on elections, they have been accompanied by injuries to others, criminal acts, deaths and destruction of property. But these incidents do not need to happen. They happen because political parties have not included within their internal structures systems that can be used to educate their members and supporters to understand that mass action is more effective when carried out in nonviolent ways. This assertion is backed by studies that have documented how political groups elsewhere have used nonviolent strategies to bring positive social change even in repressive political systems (Branagan 2013, pp. 40-44). Because political party mass actions in Kenya have a propensity for violence, law enforcement agencies have equated them with riots which they feel the need to deter through the use of lethal force, with a concomitant loss of life.

Few political parties have invested in the strengthening of internal democracy. The consequence of this was manifest during general election cycles when 
violence occurred during party nomination processes. Even though there are established systems determining how these nominations should be conducted, there have been accusations that powerful cabals within parties unfairly influence these processes to favour the candidates they prefer. And because the nomination processes are normally very competitive in the constituencies the dominant parties consider to be their strongholds ${ }^{4}$, there are often violent confrontations between supporters of opposing candidates, especially when fraud is suspected (Ogendi 2015, p. 169; Oloo 2007, p. 107).

\section{Election Violence in South Africa}

The intransigence of political party leaders in South Africa has triggered violent clashes by members on issues on which they hold radically divergent views. This manifested itself in the lead-up to the 1994 elections, when the headlines were dominated by news of political violence between ANC and IFP supporters that threatened to degenerate into a civil war. This was mainly as a result of the refusal by Chief Mangosuthu Buthelezi to allow his party, the IFP, to participate in the elections while demanding an autonomous Zulu state in the newly-formed province of KwaZulu-Natal. The cult of personality combined with an appeal to Zulu traditionalism persuaded his party loyalists to defend the party against the UDM/ANC which they considered a threat.

Notwithstanding, and as a result of local and international mediation, one crucial event that helped to de-escalate the violence was the last-minute agreement by IFP and the Freedom Party (FP) to participate in the elections. The entry of the IFP and FP played a major role in bringing down the levels of pre-election tension and preventing violence. This lends credence to Minnaar, Pretorius and Wentzel's intimation (1998, p. 24) that, even though the period before or after elections might be violent, the elections themselves are usually free of violence when all political parties agree to participate in the elections. This argument is, however, not ironclad. For instance, the Commonwealth Observer Group (2014, p. 18) reported isolated incidents of violence during subsequent elections. These include the Kwa-Dukuza shooting of an ANC party agent allegedly by an IFP supporter, and the hostage of ANC members by supporters of the EFF in Alexandra, both taking place during the 2014 national elections.

In a remarkable development in 2009, political parties recognised the risks posed by the violent activities of their members to the electoral process. Therefore, the parties that participated in that year's general election came together under

4 When a candidate obtains a party's nomination in these constituencies, he or she is almost assured of winning the seat during the ensuing elections. 
the facilitation of the IEC and signed a code of conduct. They pledged to eschew activities that encouraged violence and also to discipline any of their supporters who perpetrated violence (February 2009, p. 61).

Notwithstanding the signing of this code, recorded incidents of violence between political parties during election periods had already been on the decline since 1994. Even so, some political parties have displayed intolerance towards their competitors. As a result, and in a bid by parties to protect their political turfs, there have been many media reports of members of opposition parties being killed while campaigning (Lancaster 2014, para. 4; Nhlebela 2016, para. 1-6).

In light of the aforementioned incidents, political parties have often blamed each other for the circulation of campaign messages alleged by their competitors to incite violence. The focus of these accusations has been around the (mis)use of billboards, broadcast media and mobile phone short messaging services (SMS). At various times these disputes have landed in court (The Commonwealth 2014, p. 5). Even though the courts settle some of the disputes, they rarely resolve them completely and the respective parties continue to confront each other on issues closely linked to the settled disputes.

Curiously, intra-political party violence has also been on the rise during election periods, affecting the ANC more than the other parties. A major bone of contention is the process of developing party lists. Two factors drive the violence: firstly, contestation around fairness in the development of the lists, and secondly the quest to eliminate rivals who might seek to be on the lists. The highest incidents of intra-political party disputes have been witnessed during municipal and local government elections (Associated Press 2016, para. 4). That these elections are a powder keg of potential violence needs to be expounded further.

Municipal and local government election seats are highly sought after because they sustain patronage networks within political parties and offer benefits to the grassroots elite that have limited livelihood opportunities. Intra-party competition for opportunities to be listed for these seats is therefore intense and often leads to violence between the supporters of the respective contenders.

The intra-party clamour for municipal and local government seats does not remain within the parties. They tend to percolate into society, where the election outcomes continue to have a negative effect after the elections, and metamorphose into political violence that includes assassinations (Lancaster 2014, para. 11). This can be attributed to disputes about how lucrative tenders and other political benefits are allocated by the election winners to their political networks within their parties and beyond. Some election losers and those who fail to make it onto their parties' lists (and their networks) act out of bitterness from losing the livelihoods that could have accrued from tenders and political patronage. Another ripple effect has to do with the political undertones that can be discerned 
during public service delivery protests ${ }^{5}$ that target municipal councils which are controlled by the party or parties that won the preceding elections. Protesters are at times seen carrying placards with colours of political parties or politicians that they either support or oppose. These protests often end up in violent destruction of property and occasionally in loss of lives. The point here is that the quest to sustain patronage networks within political parties drives their members towards violent intra- and inter-party disputes, especially during the lucrative municipal and local government elections.

\section{FINDINGS}

This paper set out to examine the operations of political parties in Kenya and South Africa. In doing so, it also sought to provide an analysis of how such operations have contributed to election violence. It is evident that the actors, causes and drivers of election violence in both countries are many and complex. The emphasis in this paper is on the contribution of political parties based on the dynamics discussed in the preceding sections. In the discussion, the analysis looked not only at intra-party dynamics that govern the relationships between the members, but also at inter-party dynamics, and how different parties relate to each other.

This paper has found that the FPTP system in Kenya has promoted zerosum politics in which politicians whip up ethnic emotions and attempt to win elections at all costs. This has encouraged violence when contestations have arisen. It is important to note that political parties played a crucial role in adopting the FPTP system upon the independence of Kenya and in maintaining it in the 2010 Constitution when the opportunity arose to consider other options. Even though there have been recent constitutional amendments to introduce some elements of PR, as is the case in South Africa, further adjustments are needed in order to create a system that encourages cooperation and coalition-building between the winning and losing parties as well as between candidates. The political will for the aforementioned adjustments can be most effectively generated within and between political parties.

In its examination of the levels of institutionalisation, this paper notes that because of their longevity, political parties in South Africa have well institutionalised systems unlike in Kenya where parties have disjointed systems. Disjointed systems increase the likelihood of chaos, especially since crucial party decisions will probably be made by a cabal at the expense of the party membership.

5 Due to massive socio-economic inequalities, South Africa experiences a high volume of protests centred on the demand for housing and basic services, especially in the informal settlements. This has led to South Africa being referred to as the 'protest capital of the world' (Gaventa \& Runciman 2016, p. 72). 
Ethnicity plays a major role in determining how political parties recruit their members in both countries. Political parties in Kenya recruit their members and/ or supporters primarily on the basis of the ethnicity of the top party leaders or the regions from which they come. In South Africa, racial, ethnic and regional considerations play a large role in determining how political parties recruit their members. Whereas the statutes in Kenya prohibit recruitment of members strictly on an ethnic or regional basis, in South Africa the law allows political parties to do so. The rationale for the difference in the respective laws is due to the converse impacts that each country historically faced as far as ethnicity and racial discrimination are concerned. The common denominator is that both laws are intended to heal social rifts.

Political parties in South Africa have provided periodic spaces where members deliberate on their manifestos and this contributes to issue-based campaigns during elections. This is in stark contrast to Kenya where, during elections, the manifestos of political parties are not as important as the personalities who participate in the elections.

Another important finding of this paper is that political parties in Kenya suffer from poor internal democracy as decisions on party leadership and nominations to elective offices are often made arbitrarily by a few top party leaders. This is unlike South Africa where major political parties have elaborate internal democratic processes for the nomination of candidates both for party leadership and to run for elective offices. However, and often due to patronage, unwavering party loyalty is demanded from members who have ambitions of leading the parties or of being placed on the party lists during elections.

With regard to how political parties settle disputes, this paper notes that the laws in Kenya make specific provisions for how all intra- and inter-party disputes can be resolved. Despite this, and due to weak institutionalisation, there is a lack of trust in the internal dispute resolution mechanisms of most parties. Many disputes therefore end up in courts or are never settled. In South Africa, alternative dispute resolution mechanisms have been used in addressing problems within and between political parties before they end up in the courts or lead to unrest. This has been strengthened by the IEC-coordinated conflict management programme which serves as an early warning and response system on election violence. This has played a significant role in encouraging inter-party dialogue and preventing election violence.

\section{CONCLUSION}

This paper concludes that as a result of the way in which political parties in Kenya and South Africa are structured and operate, they have contributed to the violence 
that has become an endemic feature of the electoral processes in both countries. In Kenya, most election violence has over the years been between supporters of different political parties. The nature of operations in Kenya's political parties has fomented outbreaks of election violence. In South Africa on the other hand, even though there were many incidents of inter-party violence in the 1990s, recent trends indicate reductions of the same but with an increase in intra-party violence, especially in the ANC. Most of the election violence in South Africa is attributed to conflicts around the development of party lists for municipal and local government elections, where competition is stiff and a high premium is placed on winning seats.

\section{Acknowledgements}

The author wishes to thank Dr Marty Branagan and Dr Rebecca Spence, both of the University of New England, Armidale, for their support and initial review of this paper.

\section{- REFERENCES}

Ahere, J 2012, 'Kenyan elections, 2013: Can the precipice be avoided?', Africa Peace and Conflict Journal, vol. 5, no. 2, pp. 27-40.

André, A, Depauw, S \& Martin, S 2016, 'The classification of electoral systems: Bringing legislators back in', Electoral Studies, vol. 42, pp. 42-53.

Associated Press 2016, Deadly election season for South Africa's candidates viewed 11 August 2017, <https://goo.gl/8M2XSn>.

Barnet, T 2017, Kenya democracy: politics and ethnic influence, organization and management, Dany Beck Paper Shop, Abidjan.

Basedau, M \& Stroh, A 2008, 'Measuring party institutionalization in developing countries: A new research instrument applied to 28 African political parties ', GIGA Working Paper Series, vol. 69, <https://goo.gl/ZZ1da9>.

Booysen, S \& Masterson, G 2009, 'South Africa', in D Kadima, SBooysen \& Electoral Institute of Southern Africa (eds), Compendium of elections in Southern Africa, 1989-2009: 20 years of multiparty democracy, Electoral Institute of Southern Africa, Johannesburg, pp. 399-402.

Botha, S 1996, 'South Africa's party system', in M Faure \& J-E Lane (eds), South Africa: Designing new political institutions, SAGE Publications, London, pp. 105-20.

Branagan, M 2013, Global warming, militarism and nonviolence: The art of active resistance, Palgrave Macmillan, New York.

Chukwuemerie, AI 2009, 'Necessity as the mother of trail blazing: Applying alternative dispute resolution mechanisms to political party disputes in Africa', Journal of Politics and Law, vol. 2, no. 4, pp. 121-37. 
Cohen, M \& Mbatha, A 2017, South Africa's ruling ANC riddled by divisions, top official says, viewed 21 August 2017, <https://goo.gl/TrxukW>.

Diamond, L 2008, 'The state of democracy in Africa', paper presented to Democratization in Africa: What progress toward institutionalization?, Accra, 4-6 October 2007.

Dundas, CW 2012, Close elections and political succession in the African Union, AuthorHouse, Bloomington.

Electoral Institute for Sustainable Democracy in Africa 2006, South Africa: Party registration, viewed 9 March 2017, <https:/eisa.org.za/wep/souparties1. htm>.

Elischer, S 2010, 'Measuring and comparing party ideology in nonindustrialized societies: Taking party manifesto research to Africa', GIGA Working Papers, no. 139, viewed 24 August 2017, <https://goo.gl/f2W8BP>.

February, J 2009, 'The electoral system and electoral administration', in R Southall \& J Daniel (eds), Zunami!: The South African elections of 2009, Jacana Media, Auckland Park, pp. 47-64.

Forest, B 2007, 'The territorial politics of representation', in KR Cox, M Low \& J Robinson (eds), The SAGE handbook of political geography, SAGE Publications, Los Angeles, pp. 375-88.

Friedrich Ebert Stiftung 2010, Institutionalizing political parties in Kenya, Friedrich Ebert Stiftung (FES), Nairobi.

Gainer, M 2015, 'Transforming the courts: Judicial sector reforms in Kenya, 20112015', viewed 1 September 2017, <https://goo.gl/ihWZst>.

Gaventa, J \& Runciman, C 2016, 'Untangling economic and political inequality: The case of South Africa', in United Nations Educational Scientific and Cultural Organization, Institute of Development Studies \& International Social Science Research Council (eds), World social science report, 2016: Challenging inequalities; pathways to a just world, UNESCO Publishing, Paris, pp. 70-3.

Hofmeister, W \& Grabow, K 2011, Political parties functions and organisation in democratic societies, Konrad Adenauer Stiftung, Singapore.

Huntington, SP 2006, Political order in changing societies, Yale University Press, New Haven.

International Criminal Court 2016, Situation in the Republic of Kenya ICC-01/09, International Criminal Court, viewed 27 February 2017, <https://www.icccpi.int/kenya>.

Jolobe, Z 2009, 'The Democratic Alliance: Consolidating the official opposition', in R Southall \& J Daniel (eds), Zunami!: The South African elections of 2009, Jacana Media, Auckland Park, pp. 131-46.

Kabeberi, N2011, 'Political parties and the quest for good leadership', in O Okombo, B Muluka \& B Sungura-Nyabuto (eds), Challenging the rulers: A leadership 
model for good governance, East African Educational Publishers Limited in partnership with Community Aid International, Nairobi, pp. 117-35.

Kaßner, M 2014, The influence of the type of dominant party on democracy: a comparison between South Africa and Malaysia, Springer VS, Bonn.

Kenya 2010, The Constitution of Kenya, National Council for Law Reporting, Nairobi, $<$ https://goo.gl/BGUQXG>.

Kenya 2014, Office of the Registrar of Political Parties, 'Guide to political party membership', viewed 23 August 2017, <https://goo.gl/AsVzTQ>.

Kenya 2015, Political parties Act: No. 11 of 2011, National Council for Law Reporting, Nairobi.

Kimemia, D 2016, Africa's social cleavages and democratization: Colonial, postcolonial, and multiparty era, Lexington Books, Maryland.

Kiruthu, F 2015, 'Political party organisation in Kenya and the 2013 elections: What lessons for democracy and inclusion?', in K Njogu \& PW Wekesa (eds), Kenya's 2013 general election: Stakes, practices and outcomes, Twaweza Communications, Nairobi, pp. 64-79.

Laakso, L 2007, 'Insights into electoral violence in Africa', in MBasedau, G Erdmann \& A Mehler (eds), Votes, money and violence political parties and elections in SubSaharan Africa, Nordiska Afrikainstitutet and University of KwaZulu-Natal Press, Uppsala, pp. 224-52.

Lancaster, L 2014, Recent incidents of public violence signal a warning light for local government elections in 2016, viewed 1 September 2017, <https://goo.gl/ JCWP6z>.

Lang'at, P 2017, Agency moves to rectify irregularities in party membership fiasco, viewed 23 August 2017, <https://goo.gl/v7qEzF>.

Lodge, T 2004, 'The ANC and the development of party politics in modern South Africa', Journal of Modern African Studies, vol. 42, no. 2, pp. 189-219.

Louw, W 2014, The South African electoral system, Helen Suzman Foundation, viewed 2 March 2017, <http://hsf.org.za/resource-centre/hsf-briefs/thesouth-african-electoral-system>.

Minnaar, A, Pretorius, S \& Wentzel, M 1998, 'Political conflict and other manifestations of violence in South Africa', in E Bornman, $\mathrm{R}$ Van Eeden \& M Wentzel (eds), Violence in South Africa: A variety of perspectives, HSRC, Pretoria, pp. 13-56.

Mutizwa-Mangiza, SP 2013, 'Political party institutionalization: A case study of Kenya', Ph.D thesis, Rhodes University.

Nhlebela, M 2016, 'Our family needs closure' - son of murdered EFF member tells Malema, viewed 1 September 2017, <https://goo.gl/yPJJ5Z>.

Njogu, K (ed.) 2009, Healing the wound: Personal narratives about the 2007 post-election violence in Kenya, Twaweza Communications, Nairobi. 
O'Dwyer, C 2006, Runaway state-building: Patronage politics and democratic development, Johns Hopkins University Press, Baltimore.

Oduor, E 2017, Kenya CJ fears legal rows may interfere with polls timetable, viewed 28 August 2017, <https://goo.gl/xq714r>.

Ogendi, P 2015, 'Political parties and 'free and fair' nominations in Kenya', in MK Mbondenyi, EO Asaala, T Kabau \& A Waris (eds), Human rights and democratic governance in Kenya: A post-2007 appraisal, Pretoria University Law Press (PULP), Pretoria, pp. 149-78.

Oloo, AGR 2007, 'The contemporary opposition in Kenya: Between internal traits and state manipulation', in GR Murunga \& SW Nasong'o (eds), Kenya: The struggle for democracy, Zed Books, London, pp. 90-128.

Otenyo, EE 2016, 'Politics and the lack of labor militancy in Kenya: Trade unionism after independence', in MM Kithinji, MM Koster \& JP Rotich (eds), Kenya after 50: Reconfiguring historical, political, and policy milestones, Palgrave Macmillan New York, pp. 107-36.

Piper, L 2012, 'Further from the people - bipartisan 'nationalisation' thwarting the electoral system', in S Booysen (ed.), Local elections in South Africa: Parties, people, politics, SUN MeDIA Metro, Bloemfontein, pp. 31-44.

Randall, V \& Svåsand, L 2002, 'Political Parties and Democratic Consolidation in Africa', Democratization, vol. 9, no. 3, pp. 30-52.

Reynolds, A, Reilly, B \& Ellis, A 2008, Electoral system design: The new international IDE A handbook, International IDEA, Stockholm.

Rickards, M \& Haitsma, B 2014, 1994: The bloody miracle, C Nicklin, Cape Town. Distributed by Boondogle Films.

Ruteere, M \& Wairuri, K 2015, 'Explaining and mitigating elections-related violence and human rights violations in Kenya', in K Njogu \& PW Wekesa (eds), Kenya's 2013 general election: Stakes, practices and outcomes, Twaweza Communications, Nairobi, pp. 112-23.

Schreiner, W \& Mattes, R 2012, 'The possibilities of election campaigns as sites for political advocacy: South Africa in comparative perspective', in HA Thuynsma (ed.), Public opinion and interest group politics: South Africa's missing links?, Africa Institute of South Africa, Pretoria, pp. 154-72.

Shivambu, F \& Smith, J 2014, The coming revolution: Julius Malema and the fight for economic freedom, Jacana Media, Auckland Park.

Siko, J 2014, Inside South Africa's foreign policy: Diplomacy in Africa from Smuts to Mbeki, I. B. Tauris, London.

Teorell, J \& Lindstedt, C 2010, 'Measuring electoral systems ', Political Research Quarterly, vol. 63, no. 2, pp. 434-48.

The Commonwealth 2014, Report of the Commonwealth Observer Mission: South African national and provincial elections, viewed 1 September 2017, <https:// goo.gl/eEetij>. 
Tiry, Z 2012, 'Political parties in South African law', LLM thesis, Nelson Mandela Metropolitan University, <https://goo.gl/sz7Sbw>

Vos, PD 2017, 'Between promise and practice: Constitutionalism in South Africa more than twenty years after the advent of democracy', in M Adams, A Meuwese \& EH Ballin (eds), Constitutionalism and the rule of law: Bridging idealism and realism, Cambridge University Press, Cambridge, pp. 226-56.

Walt, Lvd 2013, 'Who rules South Africa? An anarchist/syndicalist analysis of the ANC, the post-Apartheid elite pact and the political implications', Zabalaza: A journal of southern African revolutionary anarchism, no. 13, pp. 7-12.

Wiafe-Amoako, F 2016, Africa The world today series 2016-2017, Rowman \& Littlefield Publishers, Lanham, MD.

Yoder, JC 2015, Power and politics in the book of judges: Men and women of valor, Augsburg Fortress, Minneapolis. 